\title{
И.Б. Тесленко
}

\section{КЕРАМИЧЕСКИЕ КОМПЛЕКСЫ ЗАМКА ФУНА В ЮЖНОМ КРЫМУ: КОЛЛЕКЦИЯ ПОСУДЫ ИЗ ВЫГРЕБНЫХ ЯМ*}

\begin{abstract}
Крепость Фуна является одним из ключевых памятников для изучения фортификационного зодчества Северного Причерноморья XV в. Планомерные археологические раскопки памятника проводились с 1980 г. в течение 11 полевых сезонов. К настоящему времени в деталях изучена строительная история и воссоздан архитектурный облик крепостного ансамбля Фуны, однако полная публикация материалов его раскопок остаётся актуальной. Наиболее яркие археологические комплексы относятся к завершающему этапу жизни крепости - 1459-1475 гг. Среди прочих обращали на себя внимание выгребные ямы донжона и общественного туалета возле казармы. Они были заполнены керамическим материалом, несмотря на их специфические функции. Среди частично или полностью реконструированных находок 1 двуручный кувшин, 3 кухонных горшка, 2 из которых привозные, 1 небольшой кубок и 14 глазурованных мисок. Большую часть глазурованной керамики составляют местные простые изделия и изделия сграффито, два из которых были украшены вензелем князя Александра, владельца замка. Три чаши привезены из Испании и, предположительно, из Анатолии. Их детальному анализу посвящена настоящая статья.
\end{abstract}

Ключевые слова: Южный Крым, княжество Феодоро, крепость Фуна, XV в., керамический комплекс.

Сведения об авторе: Тесленко Ирина Борисовна, кандидат исторических наук, Институт археологии Национальной академии наук Украины.

Контактная информация: 04210, Украина, г. Киев, пр-т Героев Сталинграда 12, Институт археологии Национальной академии наук Украины; e-mail: teslenko.i2016@gmail.com.

\section{I.B. Teslenko}

\section{CERAMIC ASSEMBLAGES OF THE FUNA CASTLE IN THE SOUTHERN CRIMEA: COLLECTION OF VESSELS FROM CESSPOOLS}

The Funa fortress is one of the key sites for the study of the $15^{\text {th }} \mathrm{c}$. fortification architecture of the Northern Black Sea Region. The archaeological excavations were carried out there during 11 field seasons from 1980 till 1995. To date, the history of construction has been studied in detail and the architecture of the fortress ensemble has been recreated. However, the publication of materials from excavation of the site is still an actual question. The richest archaeological assemblages relate to the final stage of the fortress's life $-1459-1475$. Cesspools of the donjon and of the public toilet near the barracks drew attention among others. They were full of ceramic material despite their specific functions. There are 1 two-handed jug, 3 kitchen pots, 2 of which are imported, 1 small goblet and 14 glazed bowls among the finds that were partially or fully reconstructed. The most of glazed ceramics are the local plain and sgraffito wares, two of which were decorated with the monogram of Prince Alexander, the owner of the castle. Three bowls are imported from Spain and, presumably, Anatolia. A detailed analysis of these findings is represented in the proposed study.

Key words: Southern Crimea, the Principality of Theodoro, the Funa fortress, the $15^{\text {th }} \mathrm{c}$., a ceramic assemblage.

\footnotetext{
* Статья поступила в номер 29 октября 2021 г. Принята к печати 15 ноября 2021 г.
} 
About the author: Teslenko Iryna, PhD (History), Institute of Archaeology of the National Academy of Sciences of Ukraine.

Contact information: 04210, Ukraine, Kyiv, Heroiv Stalinhrada ave. 12, Institute of Archaeology of the National Academy of Sciences of Ukraine; e-mail: teslenko.i2016@gmail.com.

Введение. Крепость Фуна расположена в 2,0 км к северу от с. Лучистое (Южный Крым) и в 7,1 км от побережья Чёрного моря, у подножья юго-западного склона горы Южная Демерджи, на скале Кельсенин-Хаясы, на высоте 580 м н.у.м. Крепость возведена около 1423 г. владетелями Готии - христианского княжества с ромейскими корнями, известного также под названиями Мангупского или Феодоро, на границе с приморскими владениями генуэзцев (Кирилко 2005: 6-7, 33-59; Мыц 2009: 72-86). В конце 1450-х гг., после капитальной реконструкции, она была преобразована в родовой замок феодоритов, став резиденцией принца, а затем и князя Александра (Кирилко 2005: 63, 89-107; Мыц 2009: 362-370, 401-402). Новый архитектурный ансамбль просуществовал около 16 лет и был сожжён во время экспансии турок примерно в конце июля - августе 1475 г. (Кирилко 2005: 63).

Планомерные археологические раскопки памятника проводились в течение 11 полевых сезонов - 1980-1986, 1990-1991, 1994-1995 гг. Горно-Крымской экспедицией Отдела античной и средневековой археологии Крыма ИА АН УССР, с 1992 г. - Крымского филиала ИА НАНУ, под руководством В.Л. Мыца, а затем В.П. Кирилко ${ }^{1}$. На основании полученных данных разработана детальная периодизация крепостного ансамбля Фуны, выделено 3 периода в его строительной истории: 1423, 1425-1434 или 1450-е гг., 1459-1475 гг. (Кирилко 2005: 35-81). Это позволило датировать архитектурно-археологические комплексы памятника в узких хронологических рамках, превращая материалы из них в надёжные хроноиндикаторы для второй - третьей четверти XV в. Однако, несмотря на важность полученной информации, детальная публикация итогов раскопок все ещё далека от завершения. В этой связи введение в научный оборот археологических комплексов крепости остаётся актуальным. Наиболее репрезентативные из них относятся к третьему строительному периоду, завершение которого маркируют слои пожара 1475 г. Это, в первую очередь, материалы из раскопок донжона, хозяйственного блока, обустроенного в северовосточном секторе замка, казармы, кордегардии, иных жилых и хозяйственных строений (рис. 1), которые к настоящему времени частично опубликованы (Мыц 1988: 106-108, рис. 6 , 7; 1991: 100-102, рис. 40-42; 2009: рис. 320-328; Кирилко 2005: 63-67, 214, 218 219, рис. 47-58, 166, 168; Тесленко 2016; 2020; 2021 др.). Кроме того, среди объектов инфраструктуры замка внимание привлекают два резервуара для сбора нечистот. Один из них предназначался для накопления канализационных стоков отводимых из внутренних помещений донжона, второй выполнял функцию выгребной ямы общественного отхожего места (гарнизонного туалета?), обустроенного внутри крепости, вблизи казармы (рис. $1-3$ ). Раскопки объектов осуществлялись в 1986 и 1990 г. под началом В.Л. Мыца². Найденные здесь артефакты также весьма примечательны.

\footnotetext{
${ }^{1}$ Больше об истории исследования Фуны см.: (Кирилко 2005: 12-34). Благодарю авторов раскопок за предоставленную возможность работы с материалом.

${ }^{2}$ В 1990 г. работами на крепости непосредственно руководил архитектор В.П. Кирилко. Он же вёл дневник (НА КФ ИА НАНУ. Инв. кн. 6. № 1359. П. № 1723), выполнил полевые чертежи, обмеры архитектурных объектов и рисунки ряда находок, подготовил текст отчёта и таблицы иллюстраций. В.Л. Мыц осуществлял общее руководство экспедицией, составил полевую и коллекционные описи находок (НА КФ ИА НАНУ. Инв. кн. 6. № 1359. П. № 1723), выполнил фотофиксацию исследованных объектов и некоторых артефактов.
} 
Накопитель нечистот донжона исследован в 1986 г. (НА ИА НАНУ. № 1986/25. Л. 27-28). Архитектоника сооружения детально проанализирована В.П. Кирилко (2005: 189192). Накопитель расположен с внешней стороны восточной стены жилища феодала, примыкает к ней вплотную, обустроен в котловане прямоугольной в плане формы с вертикальными стенками объёмом около 2,76 куб. м (рис. 2). При его сооружении полностью выбран культурный слой и частично разобраны стены строений, предшествовавших укреплению (рис. 2) (Кирилко 2005: 189, рис. 70). Стоки поступали в резервуар по специальному каналу, устроенному в восточной стене башни. Канал в сечении прямоугольный, размером - 18,0 × 20,0 см. Он начинался внутри второго этажа здания и завершался над резервуаром снаружи, на уровне около $0,50-0,60$ м от дневной поверхности. Основной объем ямы был заполнен рыхлым серо-зелёным грунтом, который перекрывали слои, насыщенные остатками сгоревших конструкций и продуктами разрушения каменных стен (НА ИА НАНУ. № 1986/25. Л. 28).

В нижней пачке отложений найдено 4 керамических изделия: один небольшой неполивной красноглиняный кубок, сохранившийся полностью и 3 поливные чаши, форма которых реконструирована из фрагментов (рис. 4: $1-4,7: 7,8: 5$, 9). Все изделия по визуально фиксируемым признакам могут быть отнесены к группе керамики ЮгоВосточного Крыма ${ }^{3}$. Для них характерен плотный жёлто-красный черепок с включениями мелких частиц рыхлого минерала белого цвета (известь) и мелкодроблёного шамота (заметен не всегда).

Кубок закрытой формы с шаровидным туловом, плавно переходящим в высокую монолитную ножку на расширенной опорной плоскостью (рис. 4: 1, 7: 7). Венчик слегка отогнут наружу, утончён к краю. Полезный объем сосуда составляет около 55-60 мл. Вероятно, он предназначался для употребления жидкостей. На венчике заметно пятно зелёной поливы. По-видимому, сосуд обжигался вместе с глазурованной посудой. Подобные кубки не были в массовом употреблении на территории Крыма, по крайней мере, аналогий изделию среди синхронных древностей полуострова найти пока не удалось.

Чаши относятся к двум типам: с вертикальным, прямым, профилированным небольшим выступом бортом, отделённым от корпуса чётко выраженным ребром (рис. 4: 2); со скруглённым бортом и вертикальным либо слегка отогнутым наружу венчиком, которые соответствуют типам 9.1А и 9.2В по И. Б. Тесленко (рис. 4: 3, 4), распространённым в XV в. (Тесленко 2021: 82, рис. 74).

По способу оформления внешней поверхности сосуды принадлежат к двум отделам без дополнительного декора (рис. 4: 2) и с орнаментом сграффито, подцвеченным пятнами зелёной и коричневой краски (рис. 4: 3, 4, 8: 5, 9). Полива внутри светло-жёлтая, снаружи по борту - зелёная. Декоративные мотивы типичны для крымской керамики XV в. и находят параллели как среди материалов Фуны, так и других синхронных памятников (Адаксина, Кирилко, Мыц 2003: рис. 98: 16a; Тесленко 2010: 228, рис. 4; др.).

Выгребная яма гарнизонного туалета ${ }^{4}$ исследована в 1990 г. (НА ИА НАНУ. № 1990/21a. Л. 18-19). Сооружение располагается в южной части двора 2, встроено в пространство между северной стеной хозяйственного строения XXXII, замыкающего двор с юга и капитальными кладками, ограничивавшими двор с запада и юго-востока, сложено из камня с использованием известкового раствора и глины (рис. 1-3). В плане оно прямоугольной формы. Параметры внутреннего пространства $-3,6 \times 3,8 \times 1,2$ м. Мощность

\footnotetext{
${ }^{3}$ Детальнее о группе см., напр.: (Тесленко 2010; 2021: 77-90).

4 «Помещение XXXIII» в полевой и отчётной документации (НА ИА НАНУ. № 1990/21а. Л. 18-19).
} 
культурных отложений в заполнении - 0,8-2,55 м. Структура этих напластований осложнена многочисленными слоями и прослойками. На стратиграфическом разрезе отражены на менее 18 из них (рис. 3: 5). Верхняя часть заполнения ямы образована слоями рыхлого светло-серого и зеленовато-серого грунта, насыщенного продуктами горения (фрагментами обугленных деревянных конструкций, золы, прокалённых грунта и глины) и разрушения каменных стен (камни, деструктированный известковый раствор). Слой пожара стратиграфически связан с аналогичными отложениями во дворах № 1 и 2, то есть, скорее всего, является следствием синхронного по времени события (рис. 3: 5, б). В нижней части отмечены слои зеленовато-серого и зеленовато-жёлтого грунта «с явными признаками органических остатков...» (НА ИА НАНУ. № 1990/21а. Л. 19)․․ Здесь же найдены череп и отдельные кости поросёнка, а также черепа двух взрослых особей и двух детёнышей кошачьих. Особенности структуры и состава заполнения сооружения позволили авторам раскопок интерпретировать его как выгребную яму туалета (НА ИА НАНУ. № 1990/21а. Л. 19). Верхняя, посещаемая часть строения не сохранилась ${ }^{6}$. Её пол, судя по обилию обугленных деревянных конструкций в выгребной яме, был образован, скорее всего, деревянным настилом.

Обнаруженный здесь археологический материал довольно обилен, по слоям не разделялся. Подавляющее его большинство составляют керамические изделия, отдельно отмечены «многочисленные фрагменты стеклянных чаш и сосудов, обнаруженные на самом дне ямы» ${ }^{7}$ (НА ИА НАНУ. № 1990/21а. Л. 19), а также фрагмент железного предмета неопределённого назначения, черешковый наконечник стрелы с ромбовидным острием и гвоздь (НА КФ ИА НАНУ. Инв. кн. 6. № 1359. П. № 1723. № 186-188; НА ИА НАНУ. № 1990/21a. № 63, 64). Керамика в отчёте охарактеризована бегло, на иллюстрациях представлено всего 11 предметов (НА ИА НАНУ. № 1990/21а. Л. 19, рис. 91, 104, 107, 110$112,128,130$ - 132). В разное время было опубликовано 8 наиболее примечательных изделий (Мыц 2005: 295-296; рис. 8; Тесленко 2004; 470, 487, рис. 1: 4, 2: 2, 2010: 225, рис. 3: I; 2011: 60, 61, рис. 2: 2, 3; 2014: 498-499, рис. 11: 1.1, 12: 2; 2015a: 429, рис. 2: 2, 3; 2016 : pис. 5: ж, $\partial, 6:$ : $, 7: u$; 2016: fig. 3: 7, 8, 4: 8; 2018, fig. 2: $b$ ). Общий анализ керамической коллекции ещё не предпринимался ${ }^{8}$.

В целом из заполнения выгребной ямы происходит 25 полностью или частично реконструируемых форм сосудов и 163 разрозненных фрагмента керамических изделий. Среди них обломки черепицы, пифосов, среднегабаритная тара и кухонно-столовые сосуды.

Черепица представлена двумя обломками поля и борта красноглиняной керамиды и одним краем коричневоглиняного калиптера (НА КФ ИА НАНУ, Инв. кн. 6. № 1359. П. № 1723. № 155, 156). Детальная характеристика из-за отсутствия самих изделий затруднительна.

\footnotetext{
${ }^{5}$ С внешней стороны северной стены, между двумя уровнями подсыпки двора № 2 отмечены линзы «жёлтозеленоватого и ржавого рыхлого грунта с органическими остатками» (НА ИА НАНУ. № 1990/21a. Л. 16). Возможно, в период своего функционирования выгребная яма как минимум единожды чистилась. При этом вынутое содержимое было складировано тут же, под северной стеной, во дворе № 2 и затем засыпано слоем грунта.

${ }^{6}$ Остатки её, вероятно, были окончательно разобраны при возведении каменной постройки над ямой в XVIII-XIХ вв. (НА ИА НАНУ. № 1990/21а. Л. 15, рис. 37).

${ }^{7}$ Рисунок этих сосудов, выполненный В. П. Кирилко, был опубликован В. Л. Мыцом в 2009 г. (2009: рис. 348: 1, 5-7). Их детальное изучение ещё предстоит.

${ }^{8}$ Керамический материал из раскопок Фуны 1990 г. длительное время хранился на базе Горно-Крымской археологической экспедиции в г. Алушта, в 2009-2012 гг. был обработан и передан в Алуштинский историкокраеведческий музей (филиал «Центрального музея Тавриды») автором этой статьи. Некоторые находки к тому времени были утрачены.
} 
Пифосы составляют около 44,7\% фрагментированного керамического материала. Из них около $1 / 5$ - обломки венчиков и стенок красноглиняных сосудов, сопоставимых с группой Северное Причерноморье (далее СП) ${ }^{9}$ и около 4/5 - коричневоглиняных пифосов, предположительно группы Юго-Западный Крым (далее ЮЗК) ${ }^{10}$. Часть стенок украшена налепными валиками с пальцевыми вдавлениями и орнаментом, прочерченным многорядной гребёнкой в виде волн и ломаных линий, характерным для крупногабаритной домашней тары данной группы (Тесленко 2014: 496-497, рис. 1-4).

Со среднегабаритной тарой с уверенностью можно соотнести частично реконструируемую верхнюю часть крупного двуручного кувшина группы ЮЗК, тип 1В по И. Б. Тесленко (2014: 497, рис. 8; 9), украшенного росписью белым ангобом в виде вертикальных полос (рис. 5: 3, 7: 3). Реконструируемый объем сосуда около 5-6 л. В полевой описи изображены сечения ещё двух ручек, которые могут принадлежать подобным кувшинам, однако достоверно судить об этом сложно.

Кухонно-столовая керамика более многочисленна (не менее 55\% фрагментированных керамических изделий коллекции и 24 реконструированных в разной степени форм), включает два блока изделий - неполивные и поливные.

Первый из них (41\% кухонно-столовой керамики) объединяет посуду двух различных по происхождению групп. В нём около 96\% составляют фрагменты изделий группы ЮЗК, среди которых абсолютно преобладают обломки сосудов закрытой формы. Один горшок восстановлен полностью (рис. 5: 5, 7: 2). Это крупный (объем около 5,5 л) плоскодонный, одноручный сосуд с расширенным овалоидным туловом и низким раструбообразным горлом, украшенным двумя горизонтально прочерченными бороздками. Он относится к типу 1.1А по И. Б. Тесленко (2014: 498, рис. 11). Подобные горшки были в широком употреблении в Крыму и в небольшом количестве вывозились за его пределы на протяжении XIV-XV вв. (Тесленко 2014: 498, 503, рис. 11-15). Интерес также представляют 2 обломка от сосудов предположительно зооморфных очертаний (рис. 4: 11, 12, 7: 5, 6). Один из них напоминает голову оленя с ветвистыми рогами и мог служить декоративным оформлением верхней части сосуда (рис. 4: 11, 7: б). На его поверхности сохранились остатки росписи белым ангобом в виде «ёлочки». Второй, вероятно, является фрагментом тулова этого же или другого сосуда (рис. 4: 12; 7: 5). Часть подобного изделия происходит из слоя подсыпки во дворе № 1 (Тесленко 2020, рис. 20: 1). Иные параллели отыскать пока не удалось, реконструкция формы затруднительна. Кроме того, в полевой описи отмечен обломок коричневоглиняной крышки с нижним прилепом ручки и «шишковидным навершием» (НА КФ ИА НАНУ. Инв. кн. 6, № 1359. П. № 1723. № 185) ${ }^{11}$. Подобные крышки типичны для группы ЮЗК (Тесленко 2014 : 500, рис. $11: 5.1,25,26)$.

Около 4\% представлены так называемой группой горшков с рельсовидным венчиком (далее ГРВ) $)^{12}$. Для них характерен жёлто-красный, красно-коричневый или темнокоричневый черепок, значительное количество мелкого, чёрного, блестящего остроугольного песка в формовочной массе, шероховатая поверхность и тонкие стенки. Реконструировано две полные формы и верхняя часть корпуса с венчиком и ручкой трёх одноручных горшков (рис. 5: 1, 2, 4, 7: 1, 4). Все они принадлежат к типу 1.1 по И. Б. Тесленко (2015a: 429—430,

\footnotetext{
${ }^{9}$ Детальнее о группе см.: (Тесленко 2015b: 132-135).

10 Эти изделия также отсутствуют в музейной коллекции, поэтому определение их принадлежности к группам СП и ЮЗК предположительно, однако весьма вероятно, так как именно эти две группы пифосов наиболее часто использовались в хозяйстве обитателями крепости (Тесленко 2015b). Детальную характеристику группы ЮЗК см.: (Тесленко 2014).

${ }^{11}$ Сам фрагмент в коллекции отсутствует.

12 Детальнее о группе см.: (Тесленко 2015a).
} 
рис. 1, 2). Объем восстановленных экземпляров около 1,8 и 4,0 л. Их поверхность частично пережжена до чёрного цвета, вероятно, в процессе эксплуатации. Подобная кухонная утварь появляется в Крыму около середины XV в. предположительно с территории Османского государства (Тесленко 2015a: 433-434).

Второй блок (около 59\% кухонно-столовой керамики) включает одну группу местной (ЮВК) и две - импортной посуды. Местные изделия составляют 95,5\% поливной посуды. Абсолютно преобладают сосуды открытой формы, лишь два фрагмента стенок в полевой описи отмечены как принадлежащие изделиям закрытой формы. Сосуды открытой формы представлены преимущественно чашами, предназначавшимися для индивидуального употребления пищи и напитков. Частично или полностью реконструировано 18 форм ${ }^{13}$ (рис. 4: 5-10, 6, 8: 1, 4, 7, 8, 9: 1-4). Они принадлежат к четырём морфологическими типам 9.1В, 9.2А, 9.3, 9.4В по И.Б. Тесленко (Тесленко 2021: 82, рис. 2). По способу оформления внешней поверхности эти чаши подразделяются на три отдела.

Четыре сосуда лишены дополнительного декора. Три из них переданы в музейную коллекцию (рис. 4: 5-7, 8: 1-2): одна чаша колоколовидной формы (тип 9.3), две — со скруглённым вертикальным бортом и слегка отогнутым наружу венчиком (тип 9.2А). Полива прозрачная, внутри жёлтая, снаружи по борту зелёная. На лицевой поверхности поля одной из чаш по обожжённой глине нанесено граффити в виде креста (рис. 4: б). Аналогичное по месторасположению и манере исполнения граффити отмечено на чаше из слоя пожара во дворе № 1 Фунской крепости (Тесленко 2020: рис. 11: 2).

Три чаши оформлены монограммами, выполненными в центре поля до обжига. На одной из них знак состоит из двух литер «П», расположенных одна над другой (рис. 6: 6, 8: 3) ${ }^{14}$. Подобное изображение известно на сосуде из нивелировочной подсыпки во дворе № 1 (Тесленко 2020: рис. 20: 8; 24: 9). Значение символов раскрыть пока не удалось (Мыц 2005: 295-296). На двух других чашах нанесена монограмма с центральным знаком в виде литеры «А» (рис. 6: 3, 8: 8), читаемая как Александр ${ }^{15}$. Чашки с подобным изображением довольно частая находка в крепости. Из разных объектов памятника происходит ещё не менее 16 экземпляров с аналогичными символами: по четыре - из слоя пожара донжона и двора № 1 ; четыре - из подсыпки во дворах № 1, 2 и восточной продольной улицы; одна — из заполнения пифосной ямы во дворе № 3; три - из помещений № VI (1) и XXVIII (2), примыкающих к восточной куртине ${ }^{16}$. За пределами Фуны посуда с такой монограммой пока не встречалась. Предполагается, что эти изделия составляли сервиз, выполненный по заказу владельца замка мангупского принца Александра (Мыц 1991: 101). Отмечено два стиля начертания монограммы, что может свидетельствовать о двух партиях сервиза, изготовленных разными мастерами (Мыц 2005: 295).

Остальные изделия украшены орнаментом сграффито с подцветкой мазками зелёной и коричневой краски под прозрачной, слабо окрашенной в жёлтый или зеленовато-жёлтый цвет глазурью (рис. 4: 8-10, 6: 1, 2, 4, 5, 7, 8: 4-7, 9, 9: 1-4). Большинство элементов

\footnotetext{
${ }^{13}$ Из них 6 утрачены, информация о них содержится лишь в полевой и коллекционной описях (НА КФ ИА НАНУ. Инв. кн. 6, № 1359. П. № 1723. К.о. № 39, 46, 48, 56, 57, 59), 1 из этих предметов отражён на фото в отчёте (НА ИА НАНУ. № 1990/21а. Рис. 130) и на (рис. 6: 7) к этой статье.

14 Эта же чаша была ранее опубликована В.Л. Мыцом (2005: 295-296, рис. 8: 2). Однако приведённый автором рисунок не точен, профиль, соотнесённый с этим сосудом на рис. 8: 2, не имеет к нему отношения.

${ }^{15}$ Одна из чаш утрачена.

${ }^{16}$ Из них опубликовано 6 экземпляров: две чаши из слоя пожара донжона (Мыц 1991: рис. 41: 10; $2005:$ рис. 3: 8, 9; 2009: рис. 323); две - из слоя пожара во дворе № 1 (Мыц 2005: рис. 8: 1; 2009: рис. 330; Тесленко 2010: рис. 3: I; 2016: рис. 5: ; 2020: рис. 11: 6, 7; Teslenko 2015: fig. 4); две — из подсыпки двора № 1 и восточной улицы (Тесленко 2020: рис. 20: 12, 13).
} 
декора характерно для поливной посуды XV в. (см. напр.: Адаксина, Кирилко, Мыц 2004: рис. 69, 77; 73, 86; Герцен, Науменко 2005: рис. 8; Тесленко 2010: 228, рис. 4; Teslenko 2015; 2018 ; др.). Некоторой оригинальностью отличается изображение девятилепестковой розетки, заполняющей все поле сосуда (рис. 6: 2, 9: 4). Точной аналогии ему найти пока не удалось, хотя всевозможные вариации розеток с удлинёнными миндалевидными лепестками - один из наиболее популярных мотивов декора местной керамики XV в. (Тесленко 2021: рис. 94100).

Импортная поливная посуда представлена тремя изделиями двух групп. Две чаши разные варианты испанской майолики валенсийских мастерских (рис. 6: 9, 10, 9: 6, 7) ${ }^{17}$. Одна из них украшена подглазурной кобальтовой росписью (рис. 6: 9; 9: 7) ${ }^{18}$, относится к белоголубой майолике серии Loza valenciana azul compleja (LVAC) (см., напр.: Coll Conesa 2009b: 76-79) ${ }^{19}$. Чаша полусферической формы, с вертикальным, слегка зауженным к краю венчиком, на низком, углублённом изнутри поддоне, типичная для этой декоративной группы в период с середины XIV и примерно по конец первой четверти XV вв. (Lerma et al. 1986: 187, fig. 3: 3). Рисунок покрывает лицевую поверхность изделия, состоит из трёх концентрических орнаментальных зон. В центре помещена пальметта в обрамлении четырёх равных сегментов с вертикальной штриховкой, дополненной небольшим завитком (мотив paralelas y espirales - параллели и спирали). Следующую зону заполняет пояс из расположенных зигзагообразно пальметт. Под венчиком нанесена полоса сложного орнамента из дуг, завитков и прямых линий, известного как orla de peces - рыбья окантовка.

Бело-голубая майолика производилась в мастерских Валенсии (Манисес, Патерна, Валенсия) на протяжении XIV-XV вв. В разные периоды ей были присущи различные декоративные стили с использованием различных декоративных мотивов. Стиль LVAC в целом получает распространение примерно с третьей четверти XIV в. (Coll Conesa 2009b: 76-79, 92-93). В некоторых исследованиях этот период ограничивается 1360-1450 гг. (García Porras 2012: 425). При этом отмечается, что мотив paralelas y espirales использовался непродолжительное время - преимущественно в первой половине XV в. (Gutiérres 2000: 38, fig. 2: 20a; Ray 1999: 62-64). В то же время orla de peces встречается в разных вариациях с последней четверти XIV до конца XV вв. и, как считается, являлся плодом подражания декору на китайском фарфоре династии Мин (1368-1644) (Gutiérres 2000: 38, fig. 2: 20a; Coll Conesa 2009a: 19). Ряд из пальметт более характерен для классических экземпляров LVAC (Coll Conesa 2009a: fig. 1, 3). Все три элемента декора использовались как в продукции Патерны, так и Манизеса (Francovich, Gelichi 1981: 301, tav. IV: 2-4; fig. 3; Ray 1999: 62; Coll Conesa 2009a). Наиболее близкие аналогии фунской чаше происходят из Манизеса (Валенсия, Испания), где датируются третьей четвертью XIV в. (García Porras et al. 2012: 425, fig. 1, 4: 3); из Авиньона (юго-восток Франции), где найдены в комплексе 1410-х гг. (Сarru 1995: 63, № 91); из провинции Тоскана (Италия), где атрибутированы как продукция Патерны и датированы XIV в. по аналогиям из Прованса (Francovich, Gelichi 1981: 301, tav. IV: 2-4, fig. 3). Экземпляры майолики с аналогичными орнаментальными мотивами в иных комбинациях представлены в Национальном музее керамики и изобразительного искусства Гонсалеса Марти в Валенсии и Музее керамики Манизеса, Испания (Coll Conesa 2009a: fig. 1, 3, 14, 16; 2009b: fig. 146, 147).

${ }^{17}$ Обе чаши опубликованы (Тесленко 2004: 487-488; рис. 1: 4, 2: 2), однако в данной статье уточняется атрибуция и круг аналогий изделий.

18 Эта чаша утрачена в 1990-е гг.

${ }^{19}$ О технике росписи кобальтом под оловянной глазурью см., напр.: (Coll Conesa 2009a). 
Таким образом, сочетание элементов декора на чаше из выгребной ямы в совокупности с её морфологическими особенностями и в соответствие с найденными аналогиями позволяют определить время её производства не позже первой четверти XV в. (1410-1420-х гг.?). Условия находки этого артефакта в комплексе третьего строительного периода, указывают на длительный период его использования - не менее 35-50 лет. Это, в свою очередь, может свидетельствовать как об определённой ценности предмета для его обладателя, так и о существенном запаздывании товара, доставляемого в Крым. Однако, очевидно, что в конечном итоге чаша утратил свою значимость для владельца, так как практически целое изделие было выброшено в туалет.

Вторая чаша относится к серии Losa valenciana dorada (LVD), то есть была расписана исключительно люстром поверх белой опаковой глазури (рис. 6: 10, 9: б). Корпус полусферический, с горизонтальными ручками-ушками, крепящимися к краю венчика. Уцелела примерно треть сосуда с остатками прилепа одной из ручек. Днище не сохранилось. Судя по аналогиям, оно, скорее всего, было вогнутым (см., напр: Lerma et al. 1986: 190, fig. 5; González Ballesteros 2015: 513-514, fig. 12). Красочный слой также утрачен практически полностью. Отдельные элементы рисунка в виде наклонных штрихов между двух замкнутых по обводу линий просматриваются лишь снаружи изделия. Подобный способ оформления внешней поверхности был распространён довольно широко в конце XIV - первой половине XV в., возможно и позже (см., напр: Carru 1995: 61, 64, 66-69). Несколько уточнить хронологическую позицию чаши позволяют её морфологические особенности. По наблюдениям испанских исследователей, такая форма была присуща изделиям серии LVD в первой — третьей четверти XV в. (см., напр.: Lerma et al. 1986: 190, fig. 5).

Вопрос о происхождение ещё одной чаши сплошь, корме поддона, покрытой бирюзовой глазурью, пока остаётся открытым. Сосуд полусферической формы, со слегка отогнутым наружу, скруглённым венчиком, на поддоне средней высоты, выполненном в технике кольцевого налепа, практически полностью восстановлен из 11 обломков (рис. 6: 8, 9: 5). Черепок плотный, жёлто-красный. В формовочной массе заметна примесь разнородного песка и отдельные мелкие золотистые блёстки (слюда?). В центре поля отчётливо видны отпечатки треногой разделительной подставки. На внутренней стороне дна, близко к его оси, по обожжённой глине острием прочерчено граффити в виде пучка из четырёх тонких линий.

По морфологическим характеристикам чаша близка к продукции Изника - крупного производственного центра Анатолии, более известного своими изделиями с росписью кобальтом, так называемыми Miletus Ware (далее MW) (см. напр.: Hayes 1992: 238-242, fig. 110: 8.4-73.1). Кроме MW в Изнике изготавливалась также неорнаментированная красноглиняная керамика с бирюзовой поливой (Aslanspa 1989: 283; Hayes 1992: 256). Возможно, что чаша из Фуны представляет именно эту разновидность его продукции. К тому же, группа MW присутствует на крепости в довольно значительном количестве (Тесленко 2005: 391-393; Teslenko 2007: 191-192, tab. 1). Не исключено, что бирюзовая чаша могла появиться здесь вместе с ней. Прямых аналогий изделию из синхронных комплексов найти пока не удалось.

Выводы. Таким образом очевидно, что выгребные ямы как туалета в жилище феодала, так и общественной уборной, помимо своего прямого назначения - накопления нечистот, использовались также для сброса пришедшей в негодность керамической и стеклянной посуды. Очевидно, что резервуар гарнизонного туалета использовался с этой целью чаще. Хотя и в туалет донжона, несмотря на опасность образования затора в сточном канале, также порой выбрасывались битые чаши (как минимум - три) и даже вполне пригодный для использования кубок, которые по неизвестной причине не хотели утилизировать иным 
образом, например, вынести за пределы здания. Вероятно, в данном случае посуда разбилась в одном из помещений донжона и внутренняя туалетная комната была ближайшим местом для сокрытия черепков.

В общественную уборную помимо прочего попал 1 тарный двуручный кувшин, 3 кухонных горшка и не менее 18 поливных чаш, форма которых частично или полностью реконструирована. Из них 14 сосудов (в том числе 1 местный и 2 импортных горшка, 9 местных и 2 импортных поливных чаши) восстанавливаются полностью, с минимальными утратами. То есть они, скорее всего, были выброшены вскоре после повреждения практически в полном комплекте. Попытки ремонта сосудов явно не предпринимались даже в случае с импортными изделиями. Очевидно, что владелец или владельцы посуды не испытывали недостатка в такого рода утвари.

Следует отметить, что утилизация битой керамики проходила в крепости по разному. В подсыпках дворов и улиц также найдено большое количество черепков, в том числе довольно крупных обломков разнообразной столовой посуды. Из каких соображений часть изделий использовалась в подсыпке поверхностей улиц, а часть выбрасывалась в выгребные ямы - судить сложно. Несомненно только то, что они попали туда в период с конца 1450-х до осени 1475 г.

\section{Литература}

Адаксина С.Б., Кирилко В.П., Мыц В.Л. 2003. Отчёт об археологических исследованиях средневековой крепости Чембало (2. Балаклава) в 2002 году. Санкт-Петербург: Государственный Эрмитаж.

Адаксина С.Б., Кирилко В.П., Мыц В.Л. 2004. Отчёm об археологических исследованиях средневековой крепости Чембало (2. Балаклава) в 2003 году. Санкт-Перербург; Симферополь: Государственный Эрмитаж.

Герцен А.Г., Науменко В.Е. 2005. Поливная керамика из раскопок цитадели Мангупа. В: Бочаров С.Г., Мыц В.Л. (ред.). Поливная керамика Средиземноморья и Причерноморья X-ХVIII вв. І. Киев: Стилос, 257-287.

Кирилко В.П. 2005. Крепостной ансамбль Фуны 1423-1475 г2. Киев: Стилос.

Мыц В.Л. 1988. Некоторые итоги изучения средневековой крепости Фуна. В: Бибиков С.Н. (ред.). Архитектурно-археологические исследования в Крыму. Киев: Наукова думка, 97-115.

Мыц В.Л. 1991. Укрепления Таврики $X-X V$ вв. Киев: Наукова думка.

Мыц В.Л. 2005. Историко-культурный контекст некоторых букв, монограмм и надписей на поливной керамике Крыма XIV-XV вв. В: Бочаров С.Г., Мыц В.Л. (ред.). Поливная керамика Средиземноморья и Причерноморья X-XVIII вв. І. Киев: Стилос, 288-305.

Мыц В.Л. 2009. Кафа и Феодоро в XV веке. Контакты и конфликты. Симферополь: Универсум.

НА ИА НАНУ. № 1986/25. Мыц В.Л. 1986. Отчёт об археологических исследованиях средневековых укреплений Алустон и Фуна в 1986 г.

НА ИА НАНУ. № 1990/21а. Мыц В.Л., Кирилко В.П. 1990. Отчёт о раскопках средневекового укрепления Фуна в 1990 г.

НА КФ ИА НАНУ. Инв. кн. 6. № 1359. П. № 1723. Полевой дневник арх. В.П. Кирилко по археологическому исследованию средневекового укрепления Фуна близ с. Лучистое.

НА КФ ИА НАНУ. Инв. кн. 6. № 1359. П. № 1723. Полевая опись находок из раскопок средневековой крепости Фуна в 1990 г.

Тесленко И.Б. 2004. Испанская керамика с росписью люстром в Крыму. В: Куковальская Н.М. (ред.). Сугдейский сборник. Киев; Судак: Академпериодика, 467-494.

Тесленко И.Б. 2005. Турецкая керамика с росписью кобальтом в Крыму (проблемы хронологии). В: Бочаров С.Г., Мыц В.Л. (ред.). Поливная керамика Средиземноморья и Причерноморья X-XVIII вв. І. Киев: Стилос, 385-410.

Тесленко И.Б. 2010. Поливная посуда Крыма XV в. (местное производство до турецкого периода). Ч. I: Типология, распространение, происхождение. Древности 9, 216-234. 
Тесленко И.Б. 2014. Одна из гончарных традиций Таврики XIV-XV вв. (керамика группы ЮгоЗападного Крыма). История и археология Крыма I, 495-512, 541-560.

Тесленко И.Б. 2015а. Одна из групп неполивной керамики Крыма XV в.: хронология и эволюция. История и археология Крыма II, 428-436, 636, 637.

Тесленко И. Б. 2015b. Пифосы из археологических комплексов Таврики XIV-XV вв. В: Бочаров С.Г. (отв. ред.). Крымская Газария и Золотая Орда. Кишинев: Stratum Plus, 125-163.

Тесленко И. Б. 2016. Керамика замка Фуна (Крым), краткая характеристика комплекса. В: Борисов Б.Д. (ред.). Великотърновският университет «Св. Св. Кирил и Методий» и българската археология 2. Проф. д-р Борис Борисов учениии и приятели. Велико Търново: Университетско издателство «Св. св. Кирил и Методий», 641-654.

Тесленко І.Б. 2018. Виробництво полив'яного посуду в Криму за часів Улуг Улусу. Археологія $і$ давня історія України 4 (29), 7-83.

Тесленко І.Б. 2020. Керамічні комплекси третьої чверті XV ст. замку Фуна: начиння «гарнізонної кухні». Археологія і давня історія України 1 (34), 31-67.

Тесленко И.Б. 2021. Керамика Крыма XV века. Киев: ИА НАН Украины.

Aslanspa O., Yetkin S., Altun A. 1989. The Iznik Tile Kiln Excavations (The Second Round: 1981-1988). Istanbul: The Historical Research Foundation Istanbul Research Center.

Carru D. 1995. De l'Orient à la table du Pape: L'importation des céramiques dans la région d'Avignon au Moyen âge tardif, XIVe-XVIe siècles. Documents d'archéologie vauclusienne 5. Service régional de l'archéologie, 25-75.

Coll Conesa J. 2009a. Cobalt blue in medieval ceramic production in the Valencian workshops. Manises, Paterna and Valencia, Spain. Medieval Ceramics 31, 11-24.

Coll Conesa J. 2009b. La Cerámica Valenciana (apuntes para una síntesis). Valencia: Rm Ediciones.

Francovich R., Gelichi S. 1986. La ceramica spagnola in Toscana nel Bassomedioevo. In: Zozaya J. (ed.). Segundo Coloquio Internacional de Ceramica medieval en el Mediterraneo Occidental. Madrid: Ministerio de Cultura, 297-313.

García Porras A., Coll Conesa J., Romero Pastor J., Cabella R., Cardell Fernández C., Nuevos C.C. 2012. Datos arqueométricos sobre la producción cerámica de Paterna y Manises durante el siglo XIV. In: I Congreso Internacional Red Europea de Museos de Arte Islámico. Actas. Granada: Patronato de la Alhambra y Generalife; Victoria and Albert Museum, 419-426.

González Ballesteros J.A. 2015. Aproximación al análisis de la cerámica bajomedieval de reflejo metálico en la judería del castillo de Lorca. In: Fernández Díaz A. (ed.). I encuentro de jóvenes investigadores en arqueología de la región de Murcia: de la arqueología prehistórica a la arqueología industrial. Espinardo: Servicio de Publicaciones. Universidad de Murcia, 497-538.

Gutiérres A. 2000. Mediterranean Pottery in Wessex Households (1 $3^{\text {th }}$ to $17^{\text {th }}$ centuries). Oxford: Biddles LTD (BAR 306).

Hayes J.W. 1992. Excavations at Sarachane in Istanbul. The pottery. Princeton: Princeton University Press.

Lerma J.V., Marti J., Pascual J., Soler M.P., Escriba F., Mesquida M. 1986. Sistematización de la loza gotico-mudéjar de Paterna/Manises. Atti del III Congresso internazionale La ceramica medievale nel Mediterraneo occidentale (Siena, 8-12 ottobre 1984, Faenza, 13 ottobre 1984). Firenze: All'Insegna del Giglio, 183-203.

Ray A. 1999. Spenish Pottery 1248-1898 with a catalogue of the collection in the Victoria and Albert Museum. London: V\&A publication.

Teslenko I. 2015. The Crimean Glazed Pottery of the $15^{\text {th }}$ century (Local Production before Turkish Invasion). In: Gonçalves M.J., Gómez-Martinez S. (eds.). Actas do X Congresso Internacional a cerâmica Medieval no Mediterraneo. Silves; Mértola: Gráfica commercial de Loulé, 849-854.

Teslenko I. 2018. Ceramic Import and Export of Crimea at the Final Stage of the Genoese Domination in the Black Sea Region. In: Yenişehirlioğlu F. (ed.). XI ${ }^{\text {th }}$ Congress AIECM3 on Medieval and Modern Period Mediterranean Ceramics, October 19-24, 2015, Antalya. Antalya: VEKAM, 159-163.

\section{References}

Adaksina, S.B., Kirilko, V.P., Myts, V.L. 2003. Otchet ob arheologicheskih issledovaniyah srednevekovoy kreposti Chembalo (g. Balaklava) v 2002 godu (Report on the archaeological research of the medieval fortress Cembalo (Balaklava) in 2002). Saint Petersburg: Gosudarstvennyi Ermitazh (in Russian). 
Adaksina, S.B., Kirilko, V.P., Myts, V.L. 2004. Otchyot ob arheologicheskih issledovaniyah srednevekovoy kreposti Chembalo (g. Balaklava) v 2003 godu (Report on the archaeological research of the medieval fortress Cembalo (Balaklava) in 2002). Saint Peterburg, Simferopol: Gosudarstvennyi Ermitazh (in Russian).

Gertsen, A.G., Naumenko, V.E. 2005. In: Bocharov, S.G., Myts, V.L. (eds.). Polivnaya keramika Sredizemnomorya i Prichernomorya X-XVIII vv. I (Glazed pottery of Mediterranean and Black Sea Region of the 10th - 18th centuries). Kiev: Stylos, 257-287 (in Russian).

Kirilko, V.P. 2005. Krepostnoy ansambl' Funy 1423-1475 gg. (Funa fortress ensamble of 1423-1475). Kiev: Stylos (in Russian).

Myts, V.L. 1988. In: Bibikiv S.N. (ed.). Arkhitekturno-arkheologicheskiye issledovaniya $v \quad$ Krymu (Architectural and Archaeological Research in Crimea). Kiev: Naukova dumka, 97-115. (in Russian).

Myts, V.L. 1991. Ukrepleniya Tavriki $X-X V v v$. (Fortresses of Taurica of the $10^{\text {th }}-15^{\text {th }} c c$.). Kiev: Naukova dumka (in Russian).

Myts, V.L. 2005. In: Bocharov, S.G., Myts, V.L. (eds.). Polivnaya keramika Sredizemnomorya $i$ Prichernomorya X-XVIII vv. I (Glazed pottery of Mediterranean and Black Sea Region of the $10^{\text {th }}-18^{\text {th }}$ cc.). Kiev: Stylos, 288-305 (in Russian).

Myts, V.L. 2009. Kafa i Feodoro v XV veke. Kontakty i konflikty (Caffa and Theodoro. Contacts and conflicts). Simferopol: Universum (in Russian).

NA IA NANU. № 1986/25. Myts V.L. 1986. Otchet ob arheologicheskih issledovaniyah srednevekovyh ukrepleniy Aluston i Funa v $1986 \mathrm{~g}$.

NA IA NANU. No. 1990/21a. Myts V.L., Kirilko V.P. Otchet o raskopkakh srednevekovogo ukrepleniya Funa v $1990 \mathrm{~g}$.

NA KF IA NANU. Inv. Kn. 6. No. 1359. P. No. 1723. Polevoy dnevnik arkh. V.P. Kirilko po arkheologicheskomu issledovaniyu srednevekovogo ukrepleniya Funa bliz s. Luchistoye.

NA KF IA NANU. Inv. Kn. 6. No. 1359. P. No. 1723. Polevaya opis nahodok iz raskopok srednevekovoy kreposti Funa v $1990 \mathrm{~g}$.

Teslenko, I. B. 2004. In: Kukovalskaya, N.M. (ed.). Sugdeyskiy sbornik (Sugdaia Coll lected Works). Kiev; Sudak: Academperiodika, 467-494 (in Russian).

Teslenko, I.B. 2005. In: Bocharov, S.G., Myts, V.L. (eds.). Polivnaya keramika Sredizemnomoria $i$ Prichernomoria X-XVIII vv. I (Glazed pottery of Mediterranean and Black Sea Region of the $10^{\text {th }}-18^{\text {th }}$ cc.). Kiev: Stylos, 385-410 (in Russian).

Teslenko, I.B. 2010. In Drevnosti (Antiquities) 9, 216-234 (in Russian).

Teslenko, I.B. 2014. In Istoriya i arkheologiya Kryma (History and Archaeology of Crimea) I, 495-512, $541-560$ (in Russian).

Teslenko, I.B. 2015a. In Istoriya $i$ arkheologiya Kryma (History and Archaeology of Crimea) II, 428 - 436, 636, 637 (in Russian).

Teslenko, I.B. 2015b. In: Bocharov, S.G. (ed.). Krymskaya Gazariya i Zolotaya Orda (Crimean Gazaria and Golden Horde). Kishinev: Stratum Plus, 125-163 (in Russian).

Teslenko, I. B. 2016. In: Borisov, B.D. (ed.) Velikot'rnovskiyat universitet "Sv. Sv. Kiril i Metodiy" $i$ B'lgarskata arkheologiya (Veliko Tarnovo University "St. St. Kiril and Methodius" and Bulgarian Archaeology) 2. Prof. d-r Boris Borisov uchenitsi i priyateli (Prof. Dr. Boris Borisov Students and Friends). Veliko T'rnovo: Universitetsko izdatelstvo "Sv. sv. Kiril i Metodiy”, 641 -654 (in Russian).

Teslenko, I.B. 2018. In Arkheologiya i davnia istoria Ukrainy (Archaeology and Early History of Ukraine) 4 (29), 7-83 (in Ukrainian).

Teslenko, I.B. 2020. In Arkheolohiia i davnia istoriia Ukrainy (Archaeology and Ancient History of Ukraine) 1 (34), 31-67 (in Ukrainian).

Teslenko, I.B. 2021. Keramika Kryma XV veka (Ceramics of Crimea of the $15^{\text {th }}$ century). Kiev: IA NAN Ukrainy (in Russian).

Aslanspa, O., Yetkin, S., Altun, A. 1989. The Iznik Tile Kiln Excavations (The Second Round: 1981-1988). Istanbul: The Historical Research Foundation Istanbul Research Center.

Carru, D. 1995. De l'Orient à la table du Pape: L'importation des céramiques dans la région d'Avignon au Moyen âge tardif, XIVe-XVIe siècles. Documents d'archéologie vauclusienne 5. Service régional de l'archéologie, 25-75.

Coll Conesa, J. 2009a. Cobalt blue in medieval ceramic production in the Valencian workshops. Manises, Paterna and Valencia, Spain. Medieval Ceramics 31, 11-24.

Coll Conesa, J. 2009b. La Cerámica Valenciana (apuntes para una síntesis). Valencia: Rm Ediciones. 
Francovich, R., Gelichi, S. 1986. La ceramica spagnola in Toscana nel Bassomedioevo. In: Zozaya, J. (ed.). Segundo Coloquio Internacional de Ceramica medieval en el Mediterraneo Occidental. Madrid: Ministerio de Cultura, 297-313.

García Porras, A., Coll Conesa, J., Romero Pastor, J., Cabella, R., Cardell Fernández, C., Nuevos, C.C. 2012. Datos arqueométricos sobre la producción cerámica de Paterna y Manises durante el siglo XIV. In: I Congreso Internacional Red Europea de Museos de Arte Islámico. Actas. Granada: Patronato de la Alhambra y Generalife; Victoria and Albert Museum, 419-426.

González Ballesteros, J.A. 2015. Aproximación al análisis de la cerámica bajomedieval de reflejo metálico en la judería del castillo de Lorca. In: Fernández Díaz, A. (ed.). I encuentro de jóvenes investigadores en arqueología de la región de Murcia: de la arqueología prehistórica a la arqueología industrial. Espinardo: Servicio de Publicaciones. Universidad de Murcia, 497-538.

Gutiérres, A. 2000. Mediterranean Pottery in Wessex Households (13 th $17^{\text {th }}$ centuries). Oxford: Biddles LTD (BAR 306).

Hayes, J.W. 1992. Excavations at Sarachane in Istanbul. The pottery. Princeton: Princeton University Press.

Lerma, J.V., Marti, J., Pascual, J., Soler, M.P., Escriba, F., Mesquida, M. 1986. Sistematización de la loza gotico-mudéjar de Paterna/Manises. Atti del III Congresso internazionale La ceramica medievale nel Mediterraneo occidentale (Siena, 8-12 ottobre 1984, Faenza, 13 ottobre 1984). Firenze: All'Insegna del Giglio, 183-203.

Ray, A. 1999. Spenish Pottery 1248-1898 with a catalogue of the collection in the Victoria and Albert Museum. London: V\&A publication.

Teslenko, I. 2015. The Crimean Glazed Pottery of the $15^{\text {th }}$ century (Local Production before Turkish Invasion). In: Gonçalves, M.J., Gómez-Martinez, S. (eds.). Actas do X Congresso Internacional a cerâmica Medieval no Mediterraneo. Silves; Mértola: Gráfica commercial de Loulé, 849—854.

Teslenko, I. 2018. Ceramic Import and Export of Crimea at the Final Stage of the Genoese Domination in the Black Sea Region. In: Yenişehirlioğlu, F. (ed.). XI ${ }^{\text {th }}$ Congress AIECM3 on Medieval and Modern Period Mediterranean Ceramics, October 19-24, 2015, Antalya. Antalya: VEKAM, 159-163. 


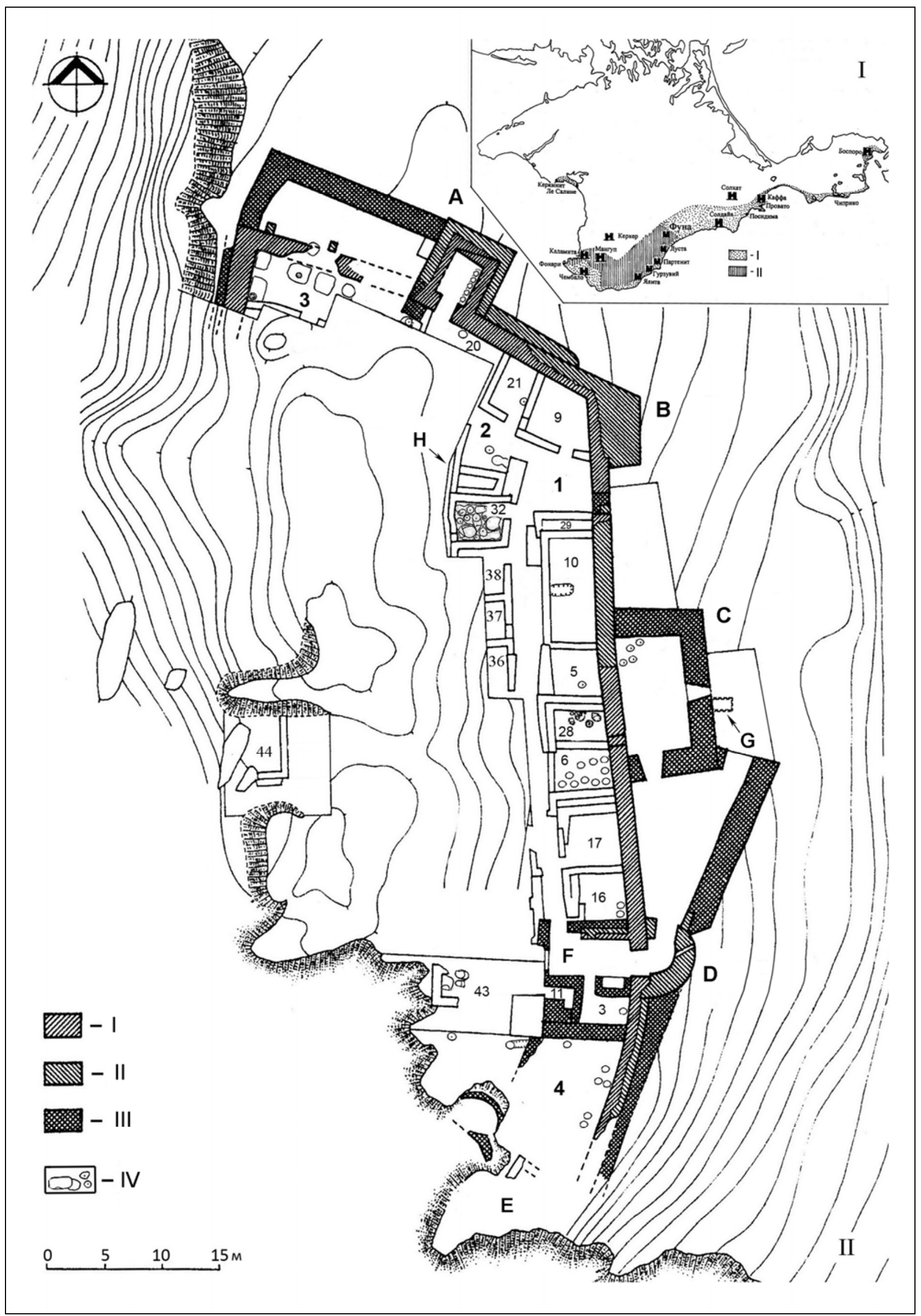


Рис. 1. Замок Фуна: I - локализация в Таврике первой четверти XV в.: $I$ - территория коммуны Генуи; II - владения Феодоро (по Мыц 2009); II - план крепости и картограмма строительных периодов фортификационных сооружений: $I-1423$ г.; II - вторая четверть XV в.; III - 1459-1475 гг. (по Кирилко 2005); $I V$ - пифосы и пифосные ямы; 1 - 4 - дворы; 9 - кордегардия; 10 - казарма; 5,6 ... 44 —жилые, хозяйственные и др. строения; $A$ - северная башня; $B$ - угловая башня; $C$ - донжон; $D$ - въездная башня; $E$ - цистерна; $F$ - надвратная церковь; $G$ - накопитель нечистот донжона; $H-$ выгребная яма гарнизонного туалета.

Fig. 1. Funa Castle: $I$ - localization in Taurica in the first quarter of the $15^{\text {th }} \mathrm{c} .: \mathrm{I}$ - territory of 'Commune di Genova'; II - possession of Theodoro principality (after Myts 2009); II — plan of the fortress and a cartogram of building periods of fortifications: $I-1423 ; I I-$ second quarter of the $15^{\text {th }} \mathrm{c}$.; $I I I-1459-1475$ (after Kirilko 2005); $I V$ - pithoi and pits; $1-4$ - yards; 9 - guardhouse; 10 - barracks; 5, $6 \ldots 44$ - dwellings and other buildings; $A-$ northern tower; $B-$ corner tower; $C$ - donjon; $D-$ entrance tower; $E-$ cistern; $F$ - gate church; $G$ - cesspool of the donjon; $H-$ cesspool of the garrison toilet. 


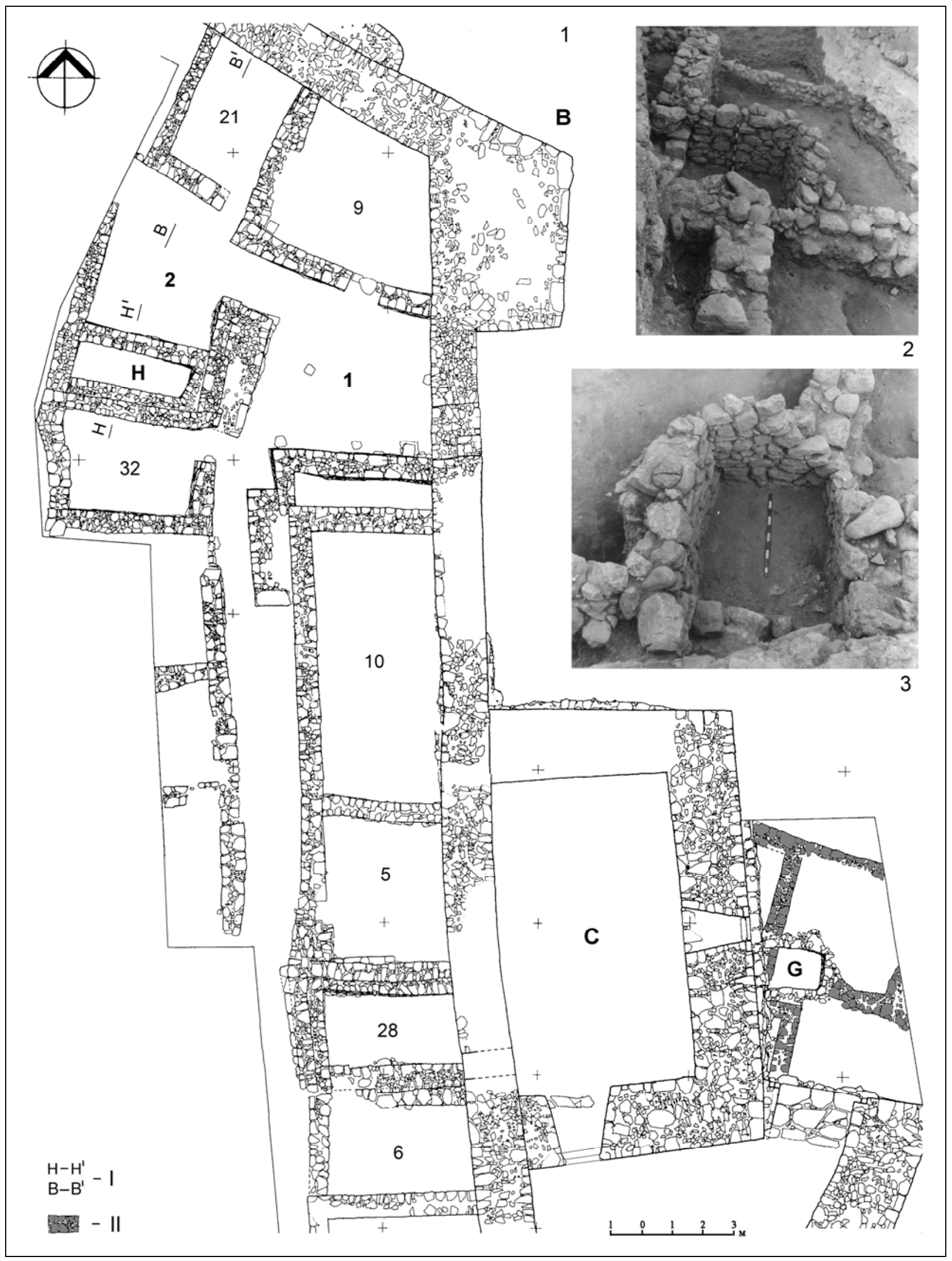


Рис. 2. Замок Фуна: 1 - план северо-восточной части крепости: $I-$ линии стратиграфических разрезов; $I I$ - остатки построек предшествовавших крепости; $B-$ угловая башня; $C$ - донжон; $G$ - накопитель нечистот донжона; $H$ - выгребная яма гарнизонного туалета; 1,2 - дворы; 9 - кордегардия; 10 - казарма; 5, 6, 21, 28, 32 - жилые и хозяйственные строения; 2 - выгребная яма донжона и остатки кладок строений, предшествовавших крепости, общий вид с юга; 3 - выгребная яма донжона, вид с запада, сверху (по Кирилко 2005).

Fig. 2. Funa Castle: 1 - plan of the north-eastern part: $I$ - lines of stratigraphic sections; $I I-$ remains of buildings that preceded the fortress; $B$ - corner tower; $C$ - donjon; $G$ - cesspool of the donjon; $H$ - cesspool of the garrison toilet; 1, 2- yards; 9 - guardhouse; 10 - barracks; 5, 6, 21, 28, 32- dwellings and storage rooms; 2 - cesspool of the donjon and the remains of the structures that existed before the fortress, a general view from the south (after Kirilko 2005); 3 - cesspool of the donjon, view from the west (after Kirilko 2005). 

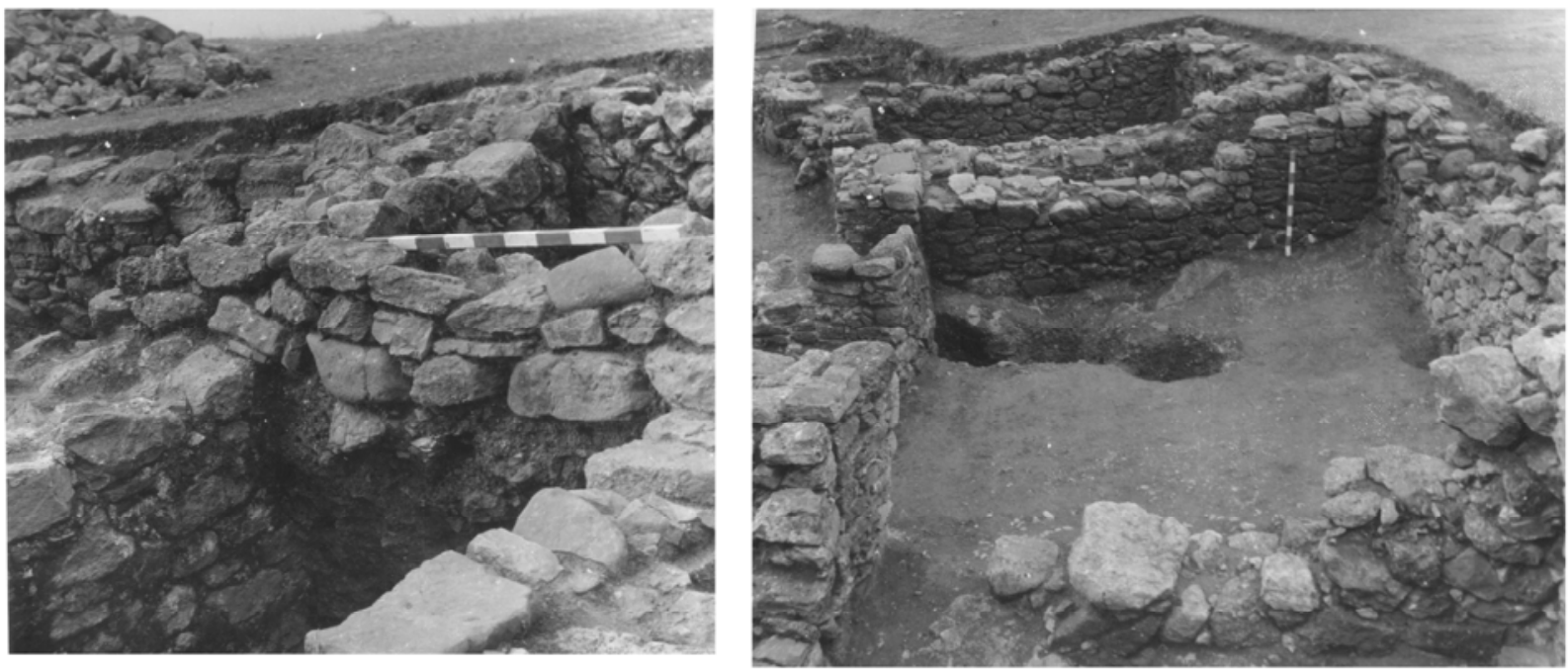

1
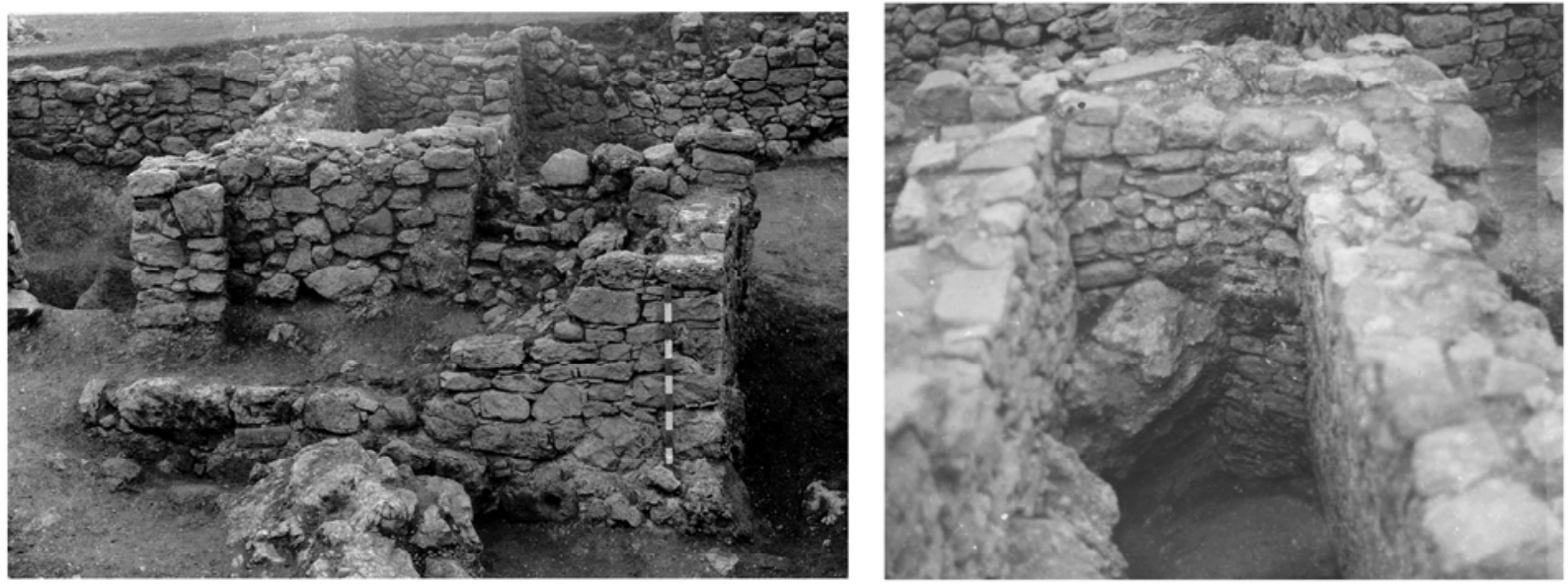

3

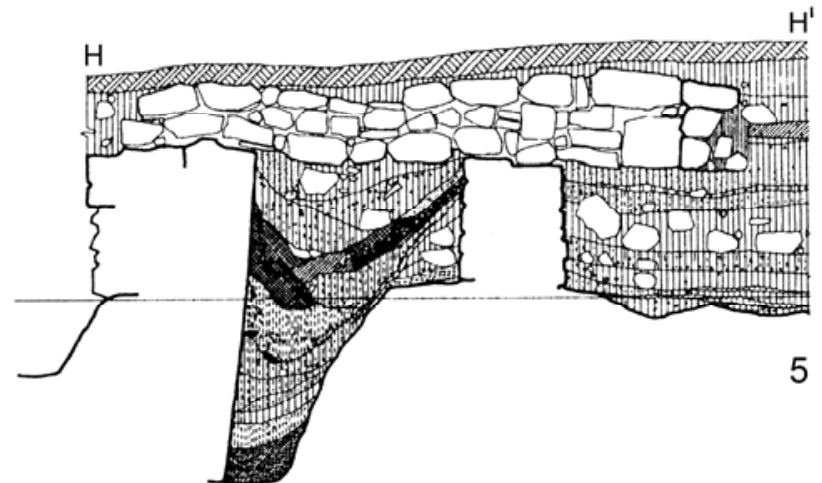

B

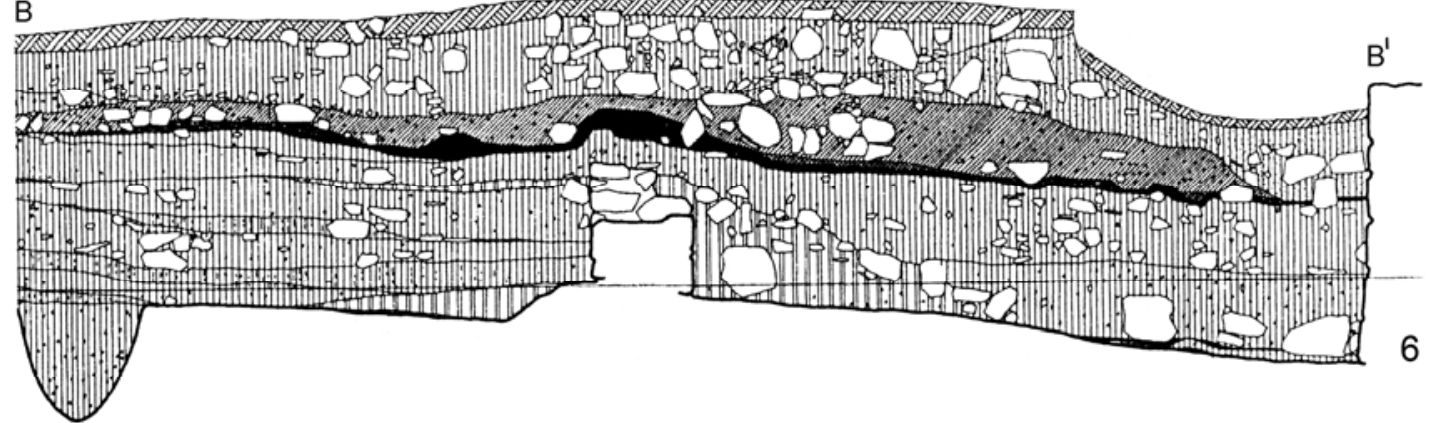


Рис. 3. Замок Фуна: 1 - кладка дома XVIII-XIX вв., перекрывавшая стены гарнизонного туалета, вид с северо-востока; 2 - двор № 2, выгребная яма гарнизонного туалета, хозяйственное строение № 32, вид с севера; 3 - проход между дворами № 1 и 2, фундамент каменной лестницы второго строительного периода (кладка № 133), выгребная яма, хозяйственное строение № 32, вид с востока; 4 - выгребная яма гарнизонного туалета, вид с запада (по НА ИА НАНУ. № 1990/21а); 5, 6 - стратиграфические разрезы.

Fig. 3. Funa Castle: $1-$ masonry of the $18^{\text {th }}-19^{\text {th }}$ cc. over the walls of the garrison toilet, view from the northeast; 2 - yard No. 2, cesspool of the garrison toilet, building No. 32, view from the north; 3 - the passage between yards No. 1 and 2, the remains of a stone staircase of the second building period (masonry No. 133), a cesspool, building No. 32, view from the east; 4 - cesspool of the garrison toilet, view from the west; 5, 6- stratigraphy. 


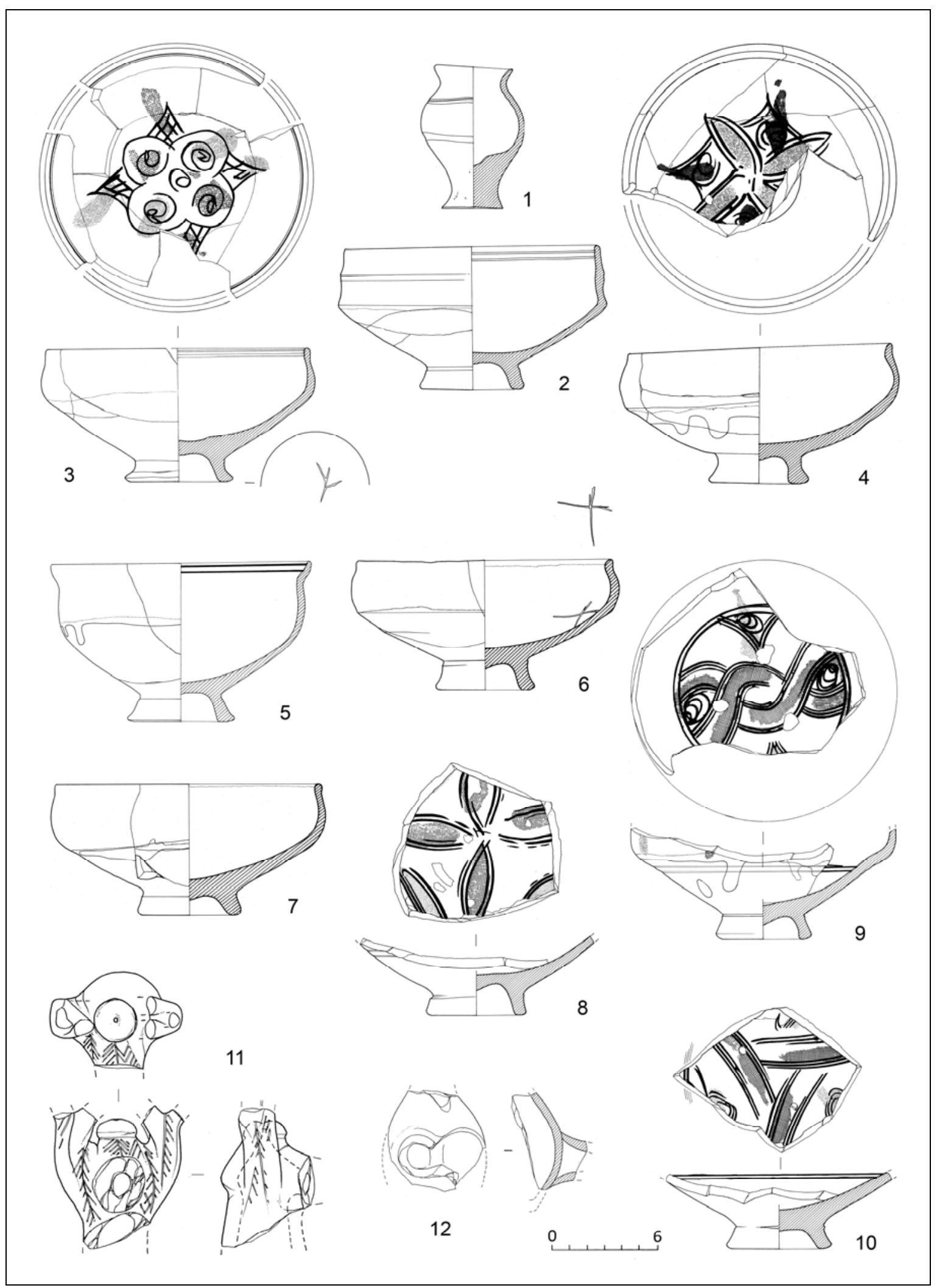

Рис. 4. Крепость Фуна, накопитель донжона (1-4) и выгребная яма гарнизонного туалета (5-12). Неполивная $(1,11,12)$ и поливная $(2-10)$ керамика: 1 - 10 - группа ЮВК; 11,12 - группа ЮЗК.

Fig. 4. Funa Fortress, the donjon $(1-4)$ and the garrison $(5-12)$ cesspools. Nonglazed $(1,11,12)$ and glazed (2-10) ceramics: $1-10$ - the Southeast Crimea Group; 11,12 - the Southwest Crimea Group. 


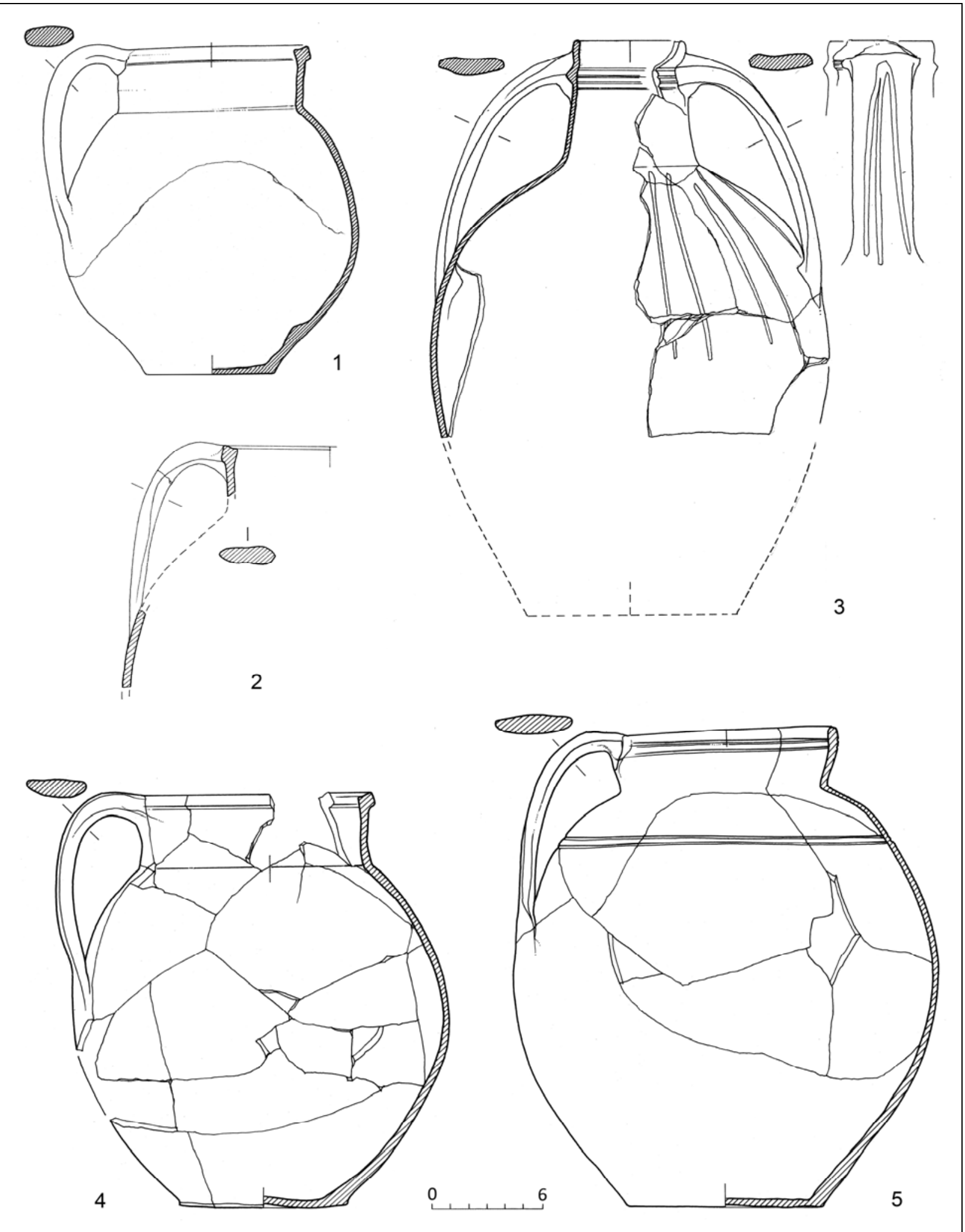

Рис. 5. Крепость Фуна, выгребная яма гарнизонного туалета. Неполивные сосуды: 1 , 2, 4 - горшки группы ГРВ; 3, 5 - кувшин и горшок группы ЮЗК.

Fig. 5. Fortress Funa; the cesspool of the garrison toilet. Nonglazed vessels: 1, 2, 4 - imported pots of the 'Pots with a Rail-shaped Rims' Group; 3, 5 - the local pitcher and a pot of the Southwest Crimea Group. 


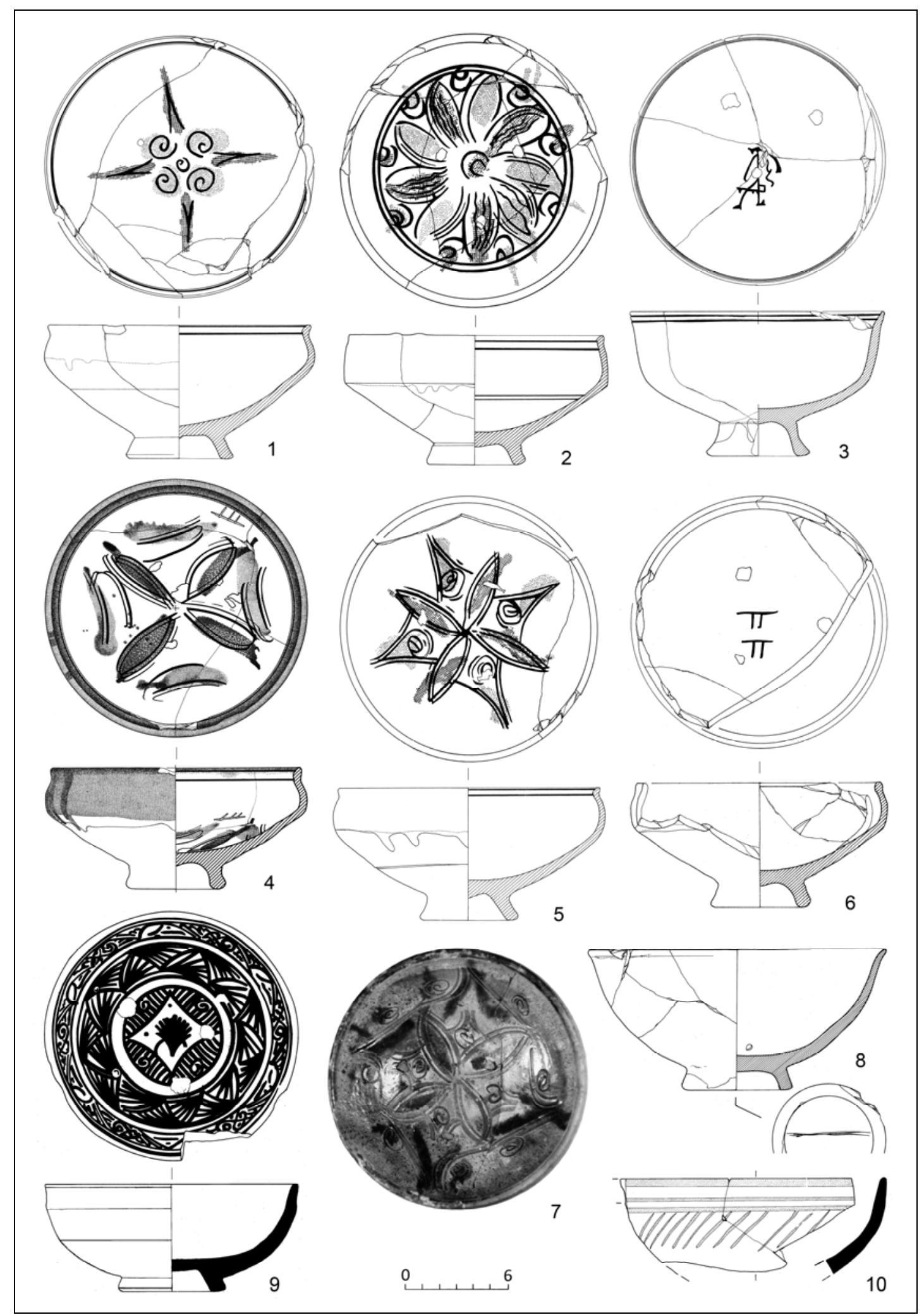

Рис. 6. Крепость Фуна, выгребная яма гарнизонного туалета. Поливная посуда: 1 -7 - чаши группы ЮВК, местное производство; 8 - чаша предположительно Анатолийского центра; 9, 10 - испанская майолика.

Fig. 6. Fortress Funa; the cesspool of the garrison toilet. Glazed ceramics: $1-7-$ local bowls of the Southeast Crimea Group; 8 - a bowl presumably from Anatolian centres; 9, 10 - Spanish Majolica. 


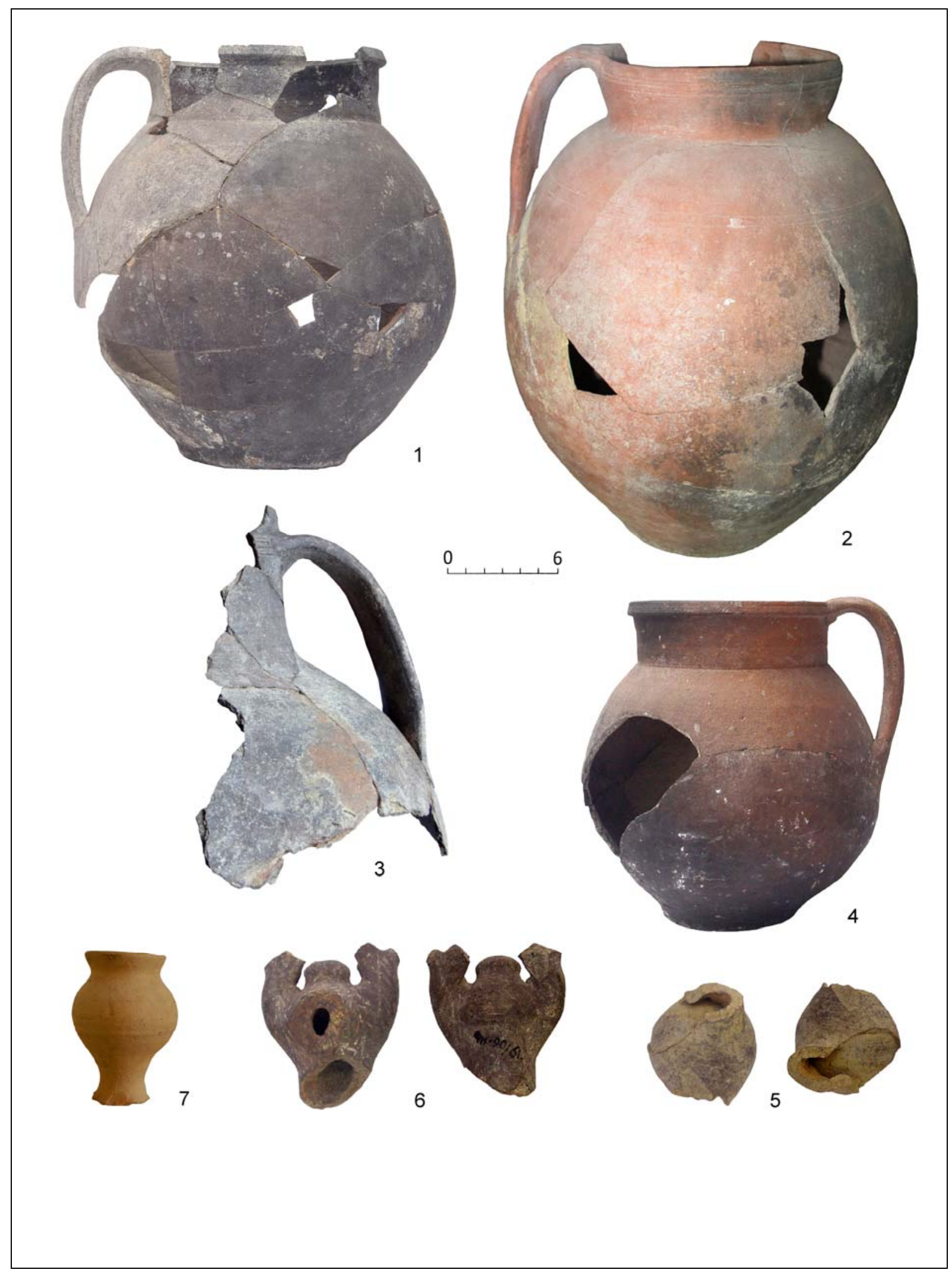

Рис.7. Крепость Фуна, выгребная яма гарнизонного туалета. Неполивная керамика: $1-6$ - группа ЮЗК; 7 - группа ЮВК.

Fig. 7. Funa Fortress; the garrison cesspools. Nonglazed ceramics: $1-6-$ the Southwest Crimea Group; 7 - the Southeast Crimea Group. 


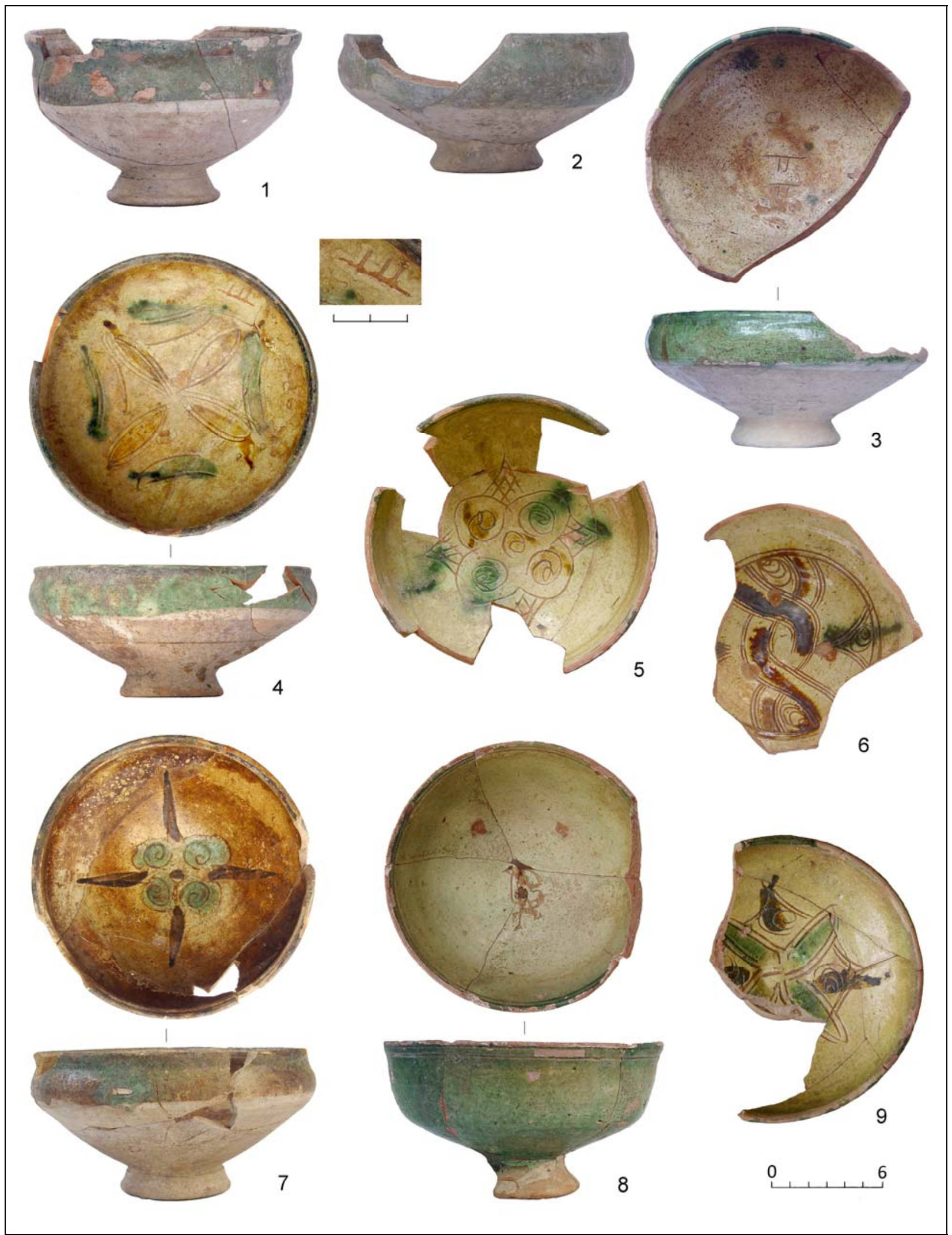

Рис. 8. Крепость Фуна, накопитель донжона $(5,9)$ и выгребная яма гарнизонного туалета ( 1 -4, 6-8). Поливная керамика, группа ЮВК.

Fig. 8. Funa Fortress; the donjon $(5,9)$ and the garrison $(1-4,6-8)$ cesspools. Glazed ceramics, the Southeast Crimea Group. 


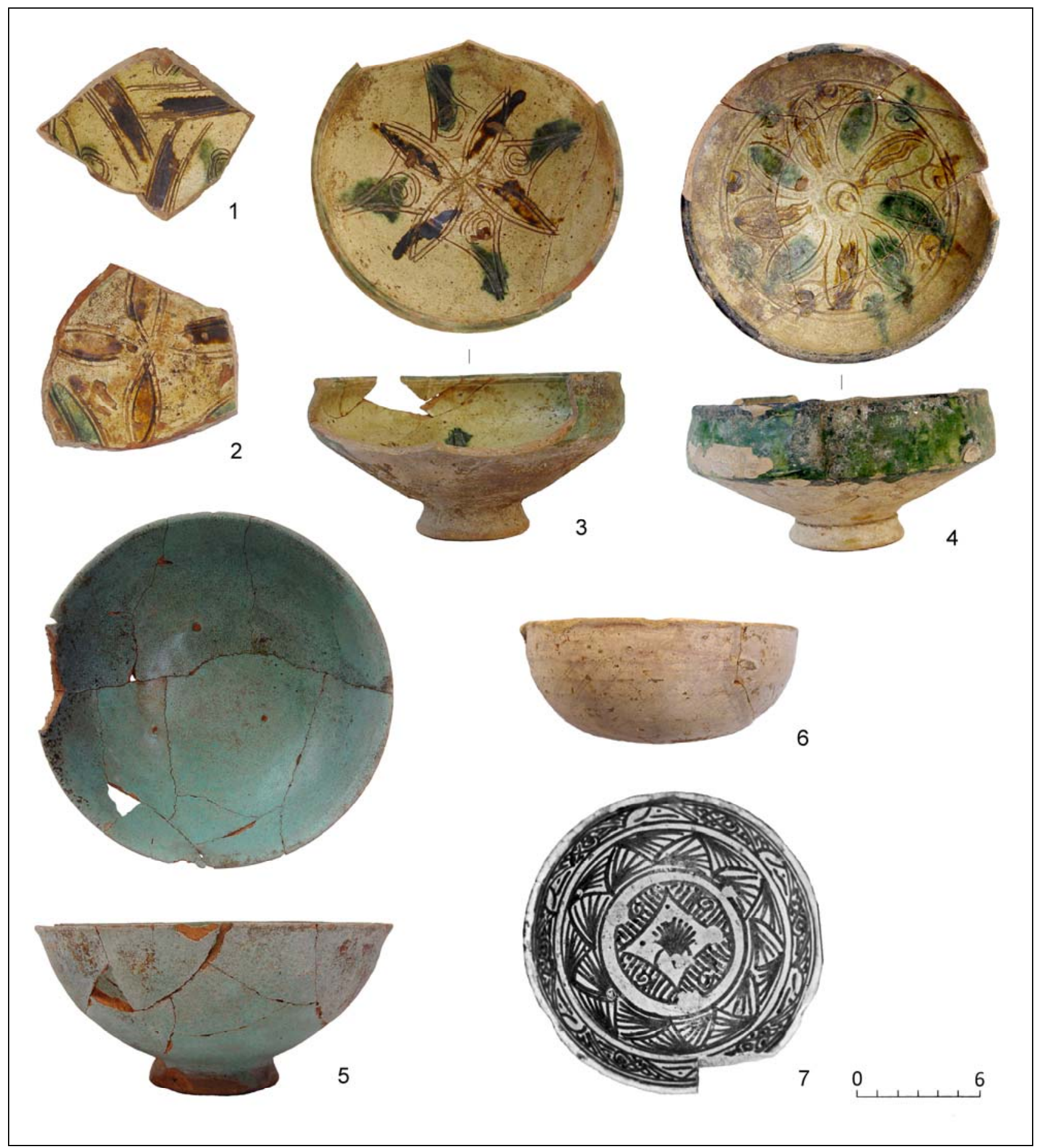

Рис. 9. Крепость Фуна, выгребная яма гарнизонного туалета. Поливная посуда: 1 - 4 - чаши группы ЮВК, местное производство; 5 - чаша предположительно Анатолийского центра; 6,7 - испанская майолика.

Fig. 9. Fortress Funa; the cesspool of the garrison toilet. Glazed ceramics: $1-4-$ local bowls of the Southeast Crimea Group; 5 - a bowl presumably from Anatolian workshop; 6, 7 - Spanish Majolica. 